\title{
Anabases
}

ANABASES Traditions et réceptions de l'Antiquité

$27 \mid 2018$

Varia

\section{Errata relatifs à l'article de James Andrews, "Revisiting the upper floors of the casa di Argo at Herculaneum » paru dans le volume 26 d'Anabases, p. 117-141.}

\section{OpenEdition}

\section{Journals}

Édition électronique

URL : http://journals.openedition.org/anabases/6719

DOI : 10.4000/anabases.6719

ISSN : 2256-9421

\section{Éditeur}

E.R.A.S.M.E.

Édition imprimée

Date de publication : 1 avril 2018

Pagination : 53

ISSN : $1774-4296$

Référence électronique

"Errata relatifs à l'article de James Andrews, « Revisiting the upper floors of the casa di Argo at Herculaneum » paru dans le volume 26 d'Anabases, p. 117-141. », Anabases [En ligne], 27 | 2018, mis en ligne le 01 avril 2018, consulté le 20 janvier 2021. URL : http://journals.openedition.org/anabases/ 6719 ; DOI : https://doi.org/10.4000/anabases.6719

Ce document a été généré automatiquement le 20 janvier 2021.

(c) Anabases 
Errata relatifs à l'article de James Andrews, «Revisiting the upper floors of the casa di Argo at Herculaneum » paru dans le volume 26 d'Anabases, p. 117-141.

1 - Lire 'Casa d'Argo' en lieu et place de 'Casa di Argo' dans le titre et l'ensemble de l'article

2 - Page 128, note 29, les références correctes sont les suivantes :Ruggiero, Storia degli scavi di Ercolano, p. 539 (21 Jan. 1828), 540, 542 (14 Feb. 1828). Bonucci's initial description of the shelving (21 Jan. 1828) includes the description of the storeroom in the general discussion of the large rectangular room, thereby not drawing a distinction between the two spaces. However, his subsequent account (14 Feb. 1828) indicates that the storeroom was at the end of the large room. Moreover, the plan provided on the same page is labelled as 'pianta della stanza e del ripostiglio descritti.'

3 - Page 135, note 52, la référence complète doit être lue comme suit :

C. Bonucci, «Ercolano », Bollettino dell'Istituto di Corrispondenza Archeologica (1829), p. 196. 